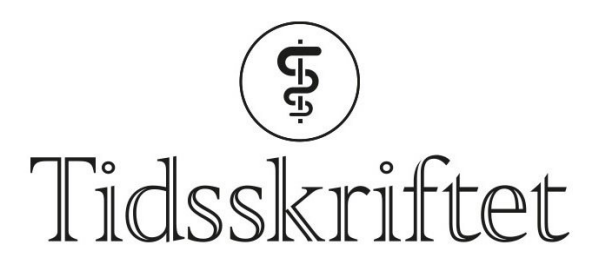

DEN NORSKE LEGEFORENING

\title{
Den nye vinen
}

MINILEDER

ARE BREAN

Sjefredaktør

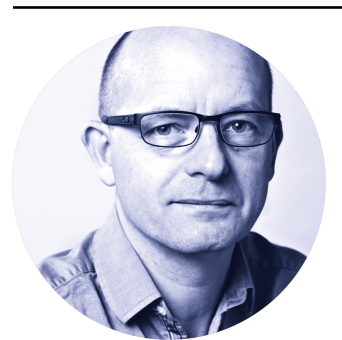

Regenerativ medisin har lenge vært den nye vinen i medisinen. Begrepet er dårlig avgrenset: Celleterapi, biomaterialteknologi, genterapi, 3 D-bioprinting - listen over «kommende» medisinske muligheter er nesten like lang som lovnadene er høye. Det snakkes om «revolusjon» innen mange terapiområder, om eventyrlig kommende vekst, sparte helseutgifter og ekspanderende markeder.

Nå heller en ny og omfattende rapport i The Lancet malurt i den nye vinen. I rapporten Stem cells and regenerative medicine konkluderer man med at «en kombinasjon av vitenskap av dårlig kvalitet, uklare finansieringsmodeller, urealistiske håp og skruppelløse privatklinikker truer den regenerative medisins sosiale lisens». Forfatterne peker på et nesten fullstendig fravær av kostnad-nytte-analyser av mange av de «lovende» nye terapiformene. Det er et økende gap mellom de urealistiske forventningene som er blitt skapt i befolkningen, og de reelle mulighetene feltet tilbyr. Høyere vitenskapelig kvalitet, sosialt ansvar, mer edruelig kommunikasjon og flere klinikere inn i preklinisk forskning er blant tiltakene man anbefaler i rapporten. Selve vannprøven for urealistiske forhåpninger er for regenerativ medisin som for alt annet: Når noe er for godt til å være sant, er det gjerne nettopp det.

Publisert: 16. oktober 2017. Tidsskr Nor Legeforen. DOI: 10.4045/tidsskr.17.19.01

(C) Tidsskrift for Den norske legeforening 2020. Lastet ned fra tidsskriftet.no 